ISSN 0206-5657. Вісник Львівського університету. Серія біологічна. 2018 Випуск 79. С. 150-154 Visnyk of the Lviv University. Series Biology. 2018. Issue 79. P. 150-154

UDC: $595.42: 638.1(477.41 / .42)$

\title{
THE FIRST DOCUMENTED RECORD OF AEROGLYPHUS PEREGRINANS (BERLESE, 1892) (ACARIDIA, AEROGLYPHIDAE) IN THE HIVES OF HONEY BEES (APIS MELLIFERA) IN UKRAINE
}

\author{
Ya. Oksentyuk \\ Zhytomyr Ivan Franko State University \\ 42, Pushkinska St., Zhytomyr 10008, Ukraine \\ e-mail: Oksentyuk_Ya@ukr.net
}

\begin{abstract}
Studying of mite communities in hives of Apis mellifera Linnaeus, 1758 in Zhytomyr region revealed Aeroglyphus peregrinans (Berlese, 1892) mites. Feeding stages of this species most frequently disperse on large carpenter bees, rarely on bumble bees, or honey bees. This is the first documented finding of A. peregrinans in beehives in Ukraine [2]. The record of $A$. peregrinans most close to Zhytomyr region was from the nature reserve "Mys Martian", Crimea. There this species were observed on Xylocopa violacea (Linnaeus, 1758). The $A$. peregrinans is a subdominant (by Shitikov's scale of dominance structure) in the mite complex of acaridia mites of honeybee hives in Zhytomyr region. Most of the specimens are recorded at the north of Zhytomyr region in Ovruch town. It is possible that the mite species can be introduced from the southern regions with bee packages and queen bees. The A. peregrinans mites were able to inhabit bee hives due to the presence of abundant feeding substrate (especially ambrosia, litter and dead bees) and the $A$. mellifera hives also provide relatively stable conditions (temperature, humidity). Seasonal fluctuations of their numbers in samples are analyzed. The $99 \%$ of mites were found in spring samples, and the remaining $1 \%$ of mites was recorded in autumn samples. This is explained by the difference in sample content; the spring samples are mostly bees which died during winter. That why most of the specimens were found in samples of dead bees. The A. peregrinans mites were absent in samples consisting mostly of ambrosia and litter (honey crystals, wax crumbs) from the hive bottom. According to the published data, previous records and our research dead bees are the main feeding substrate of the studied species in honey bee hives.
\end{abstract}

Keywords: Aeroglyphus peregrinans, honey bee hives, dead bees

Certain mite groups, such as the genus Aeroglyphus Zachvatkin, 1941, parasitize hymenopterans. Aeroglyphus mites are linked to the nests of Xylocopa bees. The genus is known from Holarctic and Afro-tropical regions. Most usually the species A. peregrinans can be found on bees of the genus Xylocopa (X. violacea and Xylocopa valga Gerstäcker, 1872), and rarely it phoreses on bumblebees (Bombus lapidarius (Linnaeus, 1758)) [4, 19]. It was rarely found in honey bee hives $[5,15]$. Representatives of the family Aeroglyphidae were also reported in bat guano $[8,15]$.

The species $A$. peregrinans was first found in Italy on $X$. violacea. It was also found in Russia near Moscow on X. violacea, X. valga and B. lapidarius [19]. In 1934, A. peregrinans was recorded in Asmi, Morocco on X. hottentotta Smith, 1854 and in near Nice, France on $X$. violacea [4]. For the first time A. peregrinans on honey bees were found by Grobov on the territory of USSR [10]. The acaridid species was observed in honey bee hives in 1975-1976 on the territory of Zlín in the Czech Republic [5, 12].

The recent finding of $A$. peregrinans was in Nature Reserve Mys Martian in 2012 (near Nikita, Crimea, Ukraine). Only seven females and six males of this species were found on $X$. violacea bees [13]. There are no other records of this species in Ukraine.

(C) Oksentyuk Ya., 2018 
Mite fauna of bee hives has been studied repeatedly in various regions of Ukraine: in Transcarpathia [7], central wood-and-steppe zone [14], in Kyiv [20], in the mixed forests (Polissia Nature Reserve, Zhytomyr region) [17]. The latter study revealed only two acaridid species, Carpoglyphus lactis and Tyrolichus casei. Previously A. peregrinans mites have not been found in hives of $A$. mellifera in Ukraine.

Hence, our study aimed to analyze the distribution of A. peregrinans in Zhytomyr region and to compare the abundance of that species in spring and autumn samples collected in hives of A. mellifera.

\section{Materials and Methods}

The material was collected during spring and autumn periods of 2015-2017 in five sites in Zhytomyr region (See Figure). Sampled material included ambrosia, litter (honey crystals, wax crumbs) and dead bees from the bottoms of honey bee hives.

Altogether 32 bee hives were examined. Only in 11 bee hives we found A. peregrinans. Mites were extracted either manually or, for quantitative analysis, in Tullgren funnels. Nearly 400 permanent slides were mounted in Hoyer's liquid [9]. Species were identified according to Cooreman [4] and Zakhvatkin [19].

The resulting data was statistically processed. Occurrence index Is, \% [16] and Paliy-Kovnatski dominance index Di, \% were calculated. The dominance scale for the latter index characterizes each species in a community as follows: eudominant (more than $10 \%$ ); dominant ( 1 to $10 \%$ ); subdominant ( 0.1 to $1 \%$ ); secondary member (less than $0.1 \%$ ) [18 with modified range denotations].

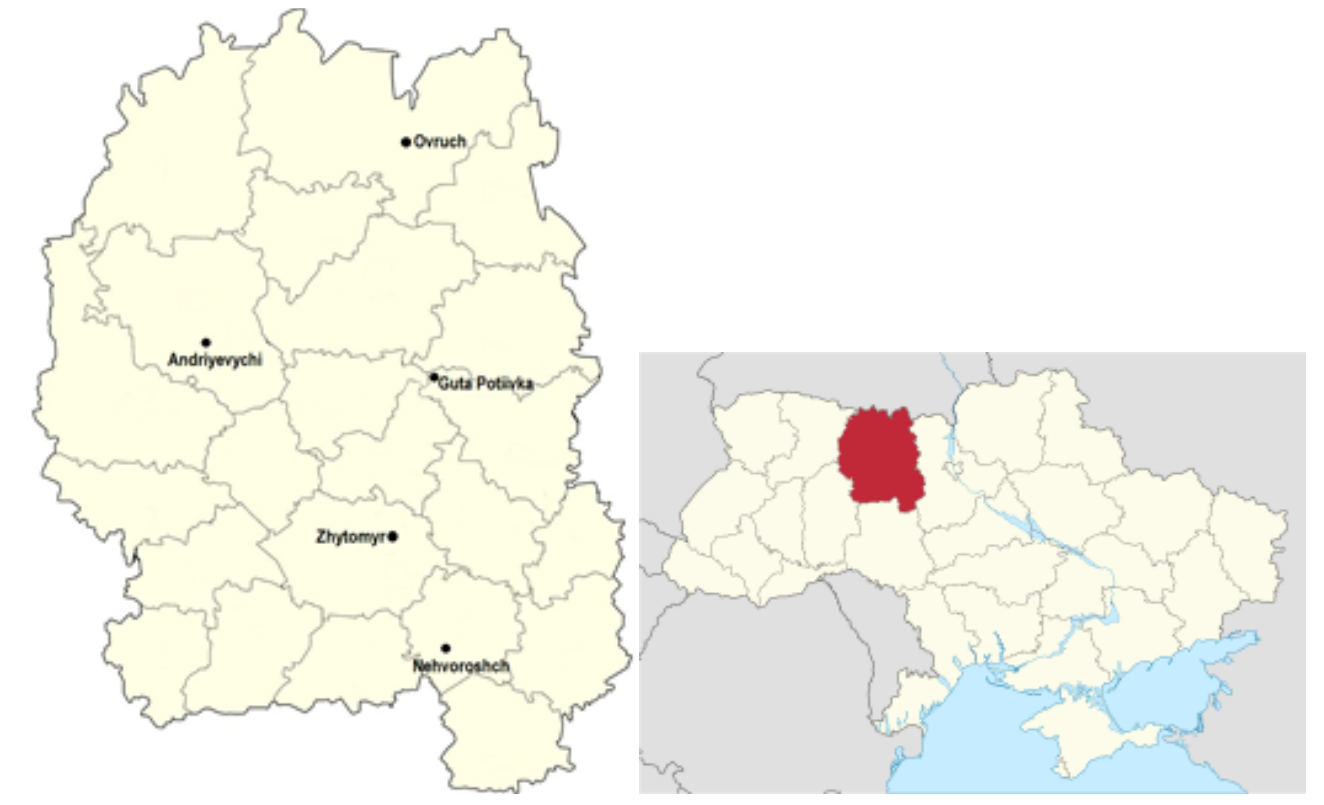

The material collecting sites (Zhytomyr region)

\section{Results and Discussion}

Our study of acaridid mites in honey bee hives of Zhytomyr region revealed a representative of the family Aeroglyphidae, A. peregrinans. The species is subdominant in the acaridid mite community of bee hives (Di $0.51 \%$ ) and occurrence index value of $54.1 \%$. The majority of $A$. peregrinans specimens $(60.5 \%)$ were collected in the north of Zhytomyr region in Ovruch 
town (See Figure). This is the first documented record of $A$. peregrinans in hives of $A$. mellifera in Ukraine [2].

According to the published data and previous records of $A$. peregrinans [4], the species prefers warmer habitats than those in Northern Ukraine. Finding it in the bee hives in Zhytomyr region can be a sign that the species spreads to the north. It is possible that the species was introduced with bee packages and queen bees from the southern regions. The abundant feeding substrate and relatively stable conditions (temperature, humidity) in hives of $A$. mellifera support the normal development and activity of $A$. peregrinans in the north of Ukraine. There are no sharp temperature fluctuations inside the hive and it never drops below $14{ }^{\circ} \mathrm{C}$ and they do not freeze in winter [17]. Average humidity in hives is 60-70\% wich are sutable for A. peregrinans [12]. Because of that, the life cycle of $A$. peregrinans lacks the hypopus stage which in other acaridid mites is important for distribution and resistance to unfavorable environmental factors. A. peregrinans has been found on inactive in winter Xylocopa carpenter bees. This is markedly different from the biological preferences of other acaridia mites, and possibly caused by the absence of hypopus so that these mites endure unfavorable conditions as eggs. However this is yet unproved.

We do not know yet the exact feeding substrate of $A$. peregrinans in hives of $A$. mellifera. The mentioned authors considered $[6,11]$ that, dead bees are the main nutritional substrate for these mites, because a lot of mite specimens have been observed in samples consisting mostly of dead bees. In samples from the beehive bottom consisting mostly of ambrosia and litter, A. peregrinans specimens were absent altogether. During winter a lot of dead bees are being accumulated at the bottom of beehive and that why the spring samples consist mostly of them. Consequently, almost all (99\%) of mites were found in spring samples, and the remaining $1 \%$ of mites was recorded in autumn samples.

The mites reportedly preferred feeding on dead bees $[6,11]$, but the causes of bee mortality remained unclear. Earlier researchers [3] supposed that $A$. peregrinans (and species of the genus Glycyphagus) can evolve from being saprophagous on dead bees to parasitic [1].

This is the first documented finding of $A$. peregrinans in beehives in Ukraine, possibly indicating developing synanthropy. The presence of this species can be explained by relatively stable conditions (temperature, humidity) and the presence of a lot of nurturing substrate which allows $A$. peregrinans to live in the Northern Ukraine. It is also possible that this species was introduced during the exchange of bee-packs and bee queens.

\section{REFERENCES}

1. Aeroglyphus / Klimov P. and others. Bee mite ID. 2018. URL: http://idtools.org/id/mites/ beemites/factsheet.php?name $=15325$

2. Akimov I. A., Oksentyuk Ya. R. Functional and ecological adaptations of several acaridid mite species (Acariformes, Astigmata) for feeding on stored produce // Vestnik Zoologii. 2018. Vol. 52. N 4. P. 553-560.

3. Blattný $C$. Roztoči v úlech a jejich poměr к Wightské nemoci // Včelařské rozhledy: měsíčník pro československé včelaře. 1924. Vol. 2. P. 90-91.

4. Cooreman J. Note sur le genre Aeroglyphus Zachvatkine, 1941 (Acaridiae, Glycyphagidae) // Bull. Inst. r. Sci. nat. Belg. Bruxelles, 1959. Vol. 35. P. 1-19.

5. De Jong D., Morse R. A., Eickwort G. C. Mite pest of honey-bees // Ann. Rev. Entomol. 1982. Vol. 27. P. 229-252.

6. Delfinado-Baker M., Baker E. W. A new record for Aeroglyphus robustus in beehive // American Bee Journal. 1982. N 122. P. 110. 
7. Dudinskiy T. T. Acarofauna of nests of the carpathian bee in the conditions of Transcarpathia: abstract of the dissertation... candidate of biological sciences. Kyiv, 1992. 16 p. (In Russian) // [Дудинский T. T. Акарофауна гнезд карпатской пчелы в условиях Закарпатья: автореф. дис. ... канд. биол. наук: 03.00.08. К., 1992. 16 с.]

8. Evans G. O. Principles of Acarology. Wallingford: C.A.B. International, 2003. 564 p.

9. Giljarov M. S. Key of soil Sarcoptiformes. Moscow: Nauka, 1975. P. 416-476. (In Russian) // [Гиляров M. C. Определитель обитающих в почве клещей Sarcoptiformes. М.: Наука, 1975. C. 416-476.]

10. Grobov O. F. Mite fauna of honeybee nests and stored honey // Works of VIEV. Moscow. 1975. Vol. 43. P. 255-267. (In Russian) // [Гробов О. Ф. Клещевая фауна гнезд медоносной пчелы и хранящегося меда // Тр. ВИЭВ. М., 1975. Т. 43. С. 255-267.]

11. Grobov O. F. Mites of the honeybee nests (Apis mellifera $\mathrm{L}$ ). Their importance and the basic principles of combating tick-borne infestations: abstract of the dissertation... doctor of biological sciences. Moscow. 1978. 26 p. (In Russian) // [Гробов О. Ф. Клещи гнезд медоносной пчелы (Apis mellifera L). Их значение и основные принципы борьбы с клещевыми поражениями: автореф. дис. ... д-ра биол. наук. М., 1978. 26 с.]

12. Haragsim O., Samšiňák K., Vobrázková E. The mites inhabiting the bee-hives in CSR // Zeitschrift fũr angewandte Entomologie. 1978. N 87. P. 52-67.

13. Khaustov A. A. To the fauna of mites of the families Chaedactylidae and Aeroglyphidae (Acari: Astigmata) phoresing on bees of the genera Xylocopa (Hymenoptera: Apidae: Xylocopinae) and Osmia (Hymenoptera: Megachilidae) in nature reserve «Mys Martian» // Scientific notes of the natural reserve «Mys Martian». 2012. N 3. P. 177-179. (In Russian) // [Хаустов A. A. К фауне клещей семейств Chaedactylidae и Aeroglyphidae (Acari: Astigmata), форезирующих на пчелах из родов Хуlocopa (Hymenoptera: Apidae: Xylocopinae) и Osmia (Нymenoptera: Megachilidae) в природном заповеднике «Мыс Мартьян» // Науч. зап. природ. заповедника «Мыс Мартьян». 2012. Вып. 3. С. 177-179.]

14. Kovalishina S. P. Acarocomplexes of bee families of Cherkasy region // Scientific Bulletin of the Pavlo Tychyna Uman State Pedagogical University. Kyiv, 2000. P. 41-46. (In Ukrainian) // [Ковалишина С. П. Акарокомплекси бджолиних сімей Черкаської області // Наук. вісн. Уман. держ. пед. ун-ту ім. Павла Тичини. К., 2000. С. 41-46.]

15. Krantz G. W., Walter D. E. A manual of acarology. Texas Tech University Press, 2009. 807 p.

16. Pesenko Yu. A. Principles and methods of quantitative analysis in faunistic studies. Moskow: Nauka, 1982. 281 p. (In Russian) // [Песенко Ю. А. Принципы и методы количественного анализа в фаунистических исследованиях. М.: Наука, 1982. 281 с.]

17. Piletskaya I. V., Zaloznaya L. M. The mites associated with honeybee Apis mellifera, inhabiting hive-logs in Polessky preserve // Vestnik zoologii. 2004. Vol. 38. N 1. P. 75-79. (In Russian) // [Пилецкая И. В., Залозная Л. М. Клещи в гнездах медоносной пчелы Apis mellifera, обитающей в ульях-колодах на территории Полесского заповедника // Вестн. зоологии. 2004. Т. 38. № 1. С. 75-79.]

18. Shitikov V. K., Rosenberg G. S., Zinchenko T. D. Quantitative hydro-ecology: methods of system identification. Tolyatti: IEVB RAN, 2003. 463 p. (In Russian) // [Шитиков В. К., Розенберг Г. С., Зинченко Т. Д. Количественная гидроэкология: методы системной идентификации. Тольятти: ИЭВБ РАН, 2003. 463 с.]

19. Zakhvatkin A. A. Arachnoidea. Moscow;Leningrad: U.S.S.R. Academy of Sciences, 1941. Vol. VI. № 1. 474 p. (In Russian) // [Захваткин A.A. Паукообразные. Москва; Ленинград: Академия Наук СССР, 1941. T. VI. Вып. 1. 474 с.] 
20. Zaloznaya L. M., Kiryushin V. E. Changes of hive acarofauna are described in a summer and winter period // Vestnik zoologii. Kiev, 2009. № 23. P. 43-47. (In Russian) // [Залозная Л. М., Кирюшин B. Е. Изменения акарофауны ульев медоносных пчел в летний и зимний период // Вестн. зоологии. 2009. № 23. С. 43-47.]

Стаття: надійшла до редакиії 21.08.18

доопрачьована 08.11.18

прийнята до друку 28.11.18

\title{
ПЕРША ЗАДОКУМЕНТОВАНА ЗНАХІДКА ВИДУ AEROGLYPHUS PEREGRINANS (AEROGLYPHIDAE) У ВУЛИКАХ МЕДОНОСНОЇ БДЖОЛИ (APIS MELLIFERA) НА ТЕРИТОРІЇ УКРАЇНИ
}

\section{Я. Оксентюк}

\author{
Житомирський державний університет імені Івана Франка \\ вул. Пушкінська, 42, Житомир 10008, Україна \\ e-mail: Oksentyuk_Ya@ukr.net
}

У результаті дослідження акарофауни вуликів медоносних бджіл Apis mellifera в Житомирській області вперше на території України виявлено поселення кліщів Aeroglyphus peregrinans, характерних для гнізд бджіл-теслярів у вуликах медоносної бджоли [2]. Дорослі особини цього виду найчастіше траплялися на великих бджолах-теслях, рідше на джмелях або медоносних бджолах. Це перша задокументована знахідка виду $A$. peregrinans у вуликах медоносної бджоли (A. mellifera) на території України. Найближче до Житомирської області вид A. peregrinans був зафіксований у заповіднику «Мис Мартьян» (Крим). Даний вид був знайдений на бджолах із роду Хylocopa, а саме на $X$. violacea. Більшість особин акарид $A$. peregrinans було зафіксовано на півночі Житомирської області у м. Овруч. Вид A. peregrinans є субдомінантом першого порядку комплексу акаридієвих кліщів бджолиних вуликів Житомирщини. Наявність даного виду пояснюється тим, що вулики медоносних бджіл характеризуються наявністю великої кількості поживного субстрату і відносно стабільними зовнішніми умовами (температура, вологість), що забезпечує можливість розвитку в ньому A. peregrinans в Україні. Не виключено, що досліджуваний вид може завозитися 3 південних районів під час обміну бджолопакетами та бджоломатками. Аналіз отриманих результатів чітко показує, що кількість особин досліджуваного виду у весняних пробах становить $99 \%$, а в осінніх - $1 \%$. Це пояснюється тим, що основу субстрату у весняних пробах становить підмор, адже за зимівлю на дні вулика з різних причин накопичується велика кількість мертвих бджіл. Отже, більшість кліщів знайдено у пробах, де переважав підмор. Особин A. peregrinans взагалі не було там, де більшість субстрату становили перга та сміття (кристали меду, воскові крихти) $з$ дна вулика. На нашу думку, підмор є основним харчовим субстратом досліджуваного виду у вуликах медоносних бджіл.

Ключові слова: Aeroglyphus peregrinans, вулики медоносних бджіл, підмор 